\title{
Quality of the Business Environment Versus Quality of Life: Do Firms and Households Like the Same Cities?
}

\author{
by
}

\author{
Stuart A. Gabriel \\ Department of Finance and Business Economics and Lusk Center for Real Estate \\ University of Southern California \\ Los Angeles, California 90089-1421 \\ Email: sgabriel@marshall.usc.edu \\ and \\ Stuart S. Rosenthal \\ Department of Economics and Center for Policy Research \\ Syracuse University \\ Syracuse, New York 13244-1020 \\ Email: ssrosent@maxwell.syr.edu
}

January 29, 2003

Rosenthal gratefully acknowledges financial support from the National Institute of Aging and the Syracuse University Center for Policy Research. Gabriel acknowledges financial support from the Faculty Research Fund of the USC Marshall School of Business. We thank Duke Kao and Glen Blomquist for helpful comments, as well as seminar participants at the University of Colorado, University of Pennsylvania, Washington University, and Wayne State University. Additional comments from two anonymous referees and the editor were also helpful. Any remaining errors, of course, are our own. 


\begin{abstract}
This paper develops a new measure of "quality of the business environment" that complements existing measures of "quality of life". An annual panel of these measures is constructed and analyzed for 37 cities from 1977 to 1995. Findings indicate that many cities attractive to firms are unattractive to households, and vice versa. In addition, the size of a city's workforce increases with the quality of the business environment while the presence of retirees declines. Additional specifications support theoretical arguments that retirees are drawn to cities in which local attributes are capitalized into lower wages rather than higher rents.
\end{abstract}




\section{Introduction}

In October 2002, Money Magazine rated Portland, Oregon as the best place to live in the United States. A few years earlier, Places Rated Almanac gave that distinction to Pittsburgh, a city once known for its aging steel industry and poor air quality. Analogous rankings are also regularly published on the best places to do business. In May 2002, Forbes ranked San Diego as the city with the best business environment in the United States. Do these rankings suggest that households and firms favor different cities? If so, what are the implications for the growth and character of individual metropolitan areas?

This paper explores these and related questions. In so doing, we emphasize that both households and firms are consumers of city-specific attributes. However, because households and firms differ in their objectives - utility versus profit maximization - they likely differ as well in their valuation of the set of attributes that characterize a given metropolitan area (denoted $\mathrm{Q}_{\mathrm{H}}$ for households and $\mathrm{Q}_{\mathrm{F}}$ for firms). Moreover, changes in $\mathrm{Q}_{\mathrm{F}}$ shift the labor demand curve of a city while changes in $\mathrm{Q}_{\mathrm{H}}$ shift the labor supply curve. These shifts affect land rents, wages, and the distribution of population across cities.

Our ability to examine these relationships requires measures of metropolitan quality of life and quality of business environment. Unfortunately, current media and academic measures fall short. On the media side, the most important shortcoming is that rankings of city quality are largely ad hoc. On the academic side, considerable progress has been made in measuring urban quality of life [see, for example, Roback (1982), Blomquist et al (1988), Gyourko and Tracy (1991), Kahn (1995), and Gabriel, Mattey, and Wascher (2001)]. Nevertheless, the literature has not provided an analogous measure of how firms value metropolitan attributes. In addition, the most comprehensive measures of quality of life have been static in nature (e.g. Blomquist et al (1988), Gyourko and Tracy (1991)). This has largely precluded study of changes in those measures over time and of the relationship between urban quality and the distribution of population across cities. Also, existing studies account for only a subset of the attributes that contribute to the quality of life and quality of business environment in any given metropolitan area.

To address these limitations, we extend the existing literature in several ways. First, we develop and estimate a measure for $\mathrm{Q}_{\mathrm{F}}$ that is grounded in economic theory. Second, we use metropolitan fixed 
effects to control for local attributes when estimating the value that agents place on the opportunity to locate in a given city: this enables us to control for the entire package of city-specific attributes. Third, we rank cities based on household and firm preferences, whereas prior studies have only considered household valuations. Finally, we construct an annual panel of $\mathrm{Q}_{\mathrm{H}}$ and $\mathrm{Q}_{\mathrm{F}}$ measures for 37 U.S. cities over the 1977-1995 period, the first such panel of its kind. This enables us to analyze the relationship between $\mathrm{Q}_{\mathrm{H}}, \mathrm{Q}_{\mathrm{F}}$, and the distribution of population across cities over time. We proceed now to the details.

\section{Quality of Life and Quality of the Business Environment}

\subsection{Conceptual Measures}

As in the existing quality of life literature (e.g. Blomquist et al (1988)), we adopt an open city model with identical mobile workers and firms. Spatial equilibrium requires that worker utility $(u)$ and firm profit $(\pi)$ are equal across metropolitan areas $(\mathrm{j}=1, \ldots, \mathrm{J})$, or

and

$$
\bar{u}=u\left(w_{j}, r_{j} \mid A_{j}\right)
$$

$$
\bar{\pi}=\pi\left(w_{j}, r_{j} \mid A_{j}\right)
$$

In (2.1) and (2.2), $w_{j}$ is the wage in city $\mathrm{j}$ relative to a given reference city, for which the wage is normalized to 1 . Similarly, $r_{j}$ is the land rent in city $\mathrm{j}$ relative to the reference city, for which the land rent is also normalized to 1 . The vector of attributes that describe city $\mathrm{j}$ is given by $A_{j}$, while $\bar{u}$ and $\bar{\pi}$ are the equilibrium levels of utility and profit in the system of cities.

Expressions (2.1) and (2.2) can be solved for the equilibrium wages and land rents in each city (see Blomquist et al (1988) and Gyourko and Tracy (1991)). Holding $A_{j}$ constant in city $\mathrm{j}$, the iso-utility curve, $\bar{u}_{j}$, traces out the set of wages and land rents that satisfy (2.1) for city $\mathrm{j}$ : this function is upward sloping because higher $w_{j}$ must be offset by higher $r_{j}$. The iso-profit curve in city $\mathrm{j}, \bar{\pi}_{j}$, traces out the set of $w$ and $r$ that satisfy (2.2): this function is downward sloping because higher $w$ must be offset by lower $r_{j}$. The intersection of $\bar{u}_{j}$ and $\bar{\pi}_{j}$ yields $w_{j}{ }^{*}$ and $r_{j}{ }^{*}$ for all $j, \ldots \mathrm{J}$, the wages and land rents in each city. 
Prior studies have also shown that metropolitan equilibrium wages and land rents can be used to measure workers' urban "quality of life." However, no such measure has been provided for firms. Accordingly, we re-write the profit function in (2.2) separating total revenue and total cost as

$$
\pi\left(w_{j}, r_{j} \mid A_{j}\right)=\mathrm{xq}-\mathrm{xc}\left(w_{j}, r_{j} \mid A_{j}\right)
$$

where $\mathrm{q}$ is product price, $\mathrm{x}$ is output, and $c\left(w_{j}, r_{j} \mid A_{j}\right)$ is the cost function. Totally differentiating the indirect profit function along an iso-profit curve, rearranging, and applying Shepard's Lemma,

$$
-c_{A} / c_{w}=\frac{L_{j}^{*}}{N_{j}^{*}} \cdot d r_{j} / d A_{j}+d w_{j} / d A_{j}
$$

In this expression, $-c_{A} / c_{w}$ is the ratio of the impact on production costs from a unit change in $A$ relative to that of a unit change in labor, or equivalently, the additional input cost a firm is willing to incur in exchange for a unit increase in $A$. Note also, that $L * / N^{*}$ is the optimal ratio of land per worker. Normalizing this value to 1 and pre-multiplying both sides of (2.3) by $A_{j}$, we get

$$
Q_{F_{j t}}=r_{j t}^{F}+w_{j t}
$$

where $r^{F}$ is the quality adjusted rent on commercial and industrial land. This expression describes the additional input costs firms are willing to incur to locate an additional worker in city $\mathrm{j}$ relative to the reference city. We refer to $\mathrm{Q}_{\mathrm{F}}$ as the "quality of the business environment".

An analogous expression for workers is obtained by starting with the indirect utility function and applying Roy’s Identity. With suitable manipulations (see Blomquist et al (1988) or Gyourko and Tracy (1991)), this yields the workers' urban "quality of life," where $r^{H}$ is the quality adjusted rent on residential land and $Q_{\mathrm{H}}$ is the amount of real wage families would be willing to give up to live in city $\mathrm{j}$ :

$$
Q_{H_{j t}}=r_{j}^{H}-w_{j} .
$$

\subsection{Empirical Measures of $Q_{H}$ and $Q_{F}$}

Estimates of the city attribute valuations are constructed as follows. As in Blomquist et al (1988) and Gyourko and Tracy (1991), wage and building rents for individual $i$, city $j$, and year $t$, are specified as 


$$
\log \left(w_{i j_{t}}\right)=\alpha_{w_{o t}}+\alpha_{w_{I_{t}}} Z_{i j_{t}}+\gamma_{w_{j_{t}}} D_{i j_{t}}+u_{w_{i j_{t}}}
$$

and

$$
\log \left(r_{i j t}\right)=\alpha_{r_{o_{t}}}+\alpha_{r_{l_{t}}} X_{i j_{t}}+\gamma_{r_{j_{t}}} D_{i j_{t}}+u_{r_{i j_{t}}}
$$

where $\mathrm{Z}_{i j t}$ controls for worker traits and $\mathrm{X}_{i j t}$ controls for characteristics of the buildings. ${ }^{1}$

As noted earlier, prior studies augment these regressions with city-specific attributes. That approach, however, is both data intensive and is at risk of omitting important local attributes. As an alternative, we control for metropolitan area attributes by including metropolitan fixed effects for each city, $\mathrm{D}_{j t}$, in (2.6) and (2.7). Having controlled for the observable quality of the worker's skill level and the building's structural attributes through $\mathrm{Z}$ and $\mathrm{X}$, the estimated fixed effects $\left(\gamma_{w j t}\right.$ and $\left.\gamma_{r j t}\right)$ reflect all remaining location-specific attributes that affect intermetropolitan variation in wages and property values at time $t$. This includes traditional descriptors of a city, such as air quality, crime, and the like, as well as aggregate characteristics of the population and housing stock not directly captured by $\mathrm{Z}$ and $\mathrm{X}$. These latter features are also attributes of the city and for that reason do not obscure interpretation of the results.

Expressions (2.6) and (2.7) are estimated separately for each time period. This yields a panel of estimated fixed effects, $\gamma_{w j t}$ and $\gamma_{r j t}$, that are used to construct quality adjusted wages and rents as follows:

$$
w_{j_{t}} \equiv \frac{\partial w_{j_{t}}}{\partial D_{j_{t}}}=\hat{\gamma}_{w_{j t}} e^{\left[\hat{\alpha}_{w_{o_{t}}}+\hat{\alpha}_{w_{l_{t}}} \bar{z}_{j_{t}}+\hat{\gamma}_{w_{j_{t}}} \bar{D}_{j_{t}}\right]}
$$

and

$$
r_{j_{t}} \equiv \frac{\partial r_{j_{t}}}{\partial D_{j_{t}}}=\hat{\gamma}_{r_{j_{t}}} e^{\left[\hat{\alpha}_{r_{o_{t}}}+\hat{\alpha}_{r_{t}} \bar{X}_{j_{t}}+\hat{\gamma}_{r_{j_{t}}} \bar{D}_{j_{t}}\right]}
$$

\footnotetext{
${ }^{1}$ In the actual regressions, wage regressors included age and age squared of the worker and spouse, white versus non-white, number of children under age 6 in the family, and number of children between age 6 to 18 in the family. In addition, each of the age variables for both the individual and spouse were separately interacted with four education categories: high school degree, some college, 4-year college degree, and more than a college degree, where less than a high school was the omitted category. Rent regressors included whether the unit was single-family detached, attached or multi-family, number of rooms, number of bedrooms, presence of a garage, presence of a basement, number of bathrooms, central air conditioning, room air conditioning, central heat, abandoned buildings on the street, age of building, whether HUD characterizes the building as being dilapidated, and central city status.
} 
where $\bar{Z}, \bar{X}$, and $\bar{D}$ are fixed at reference values such that the only variation in $w_{j t}$ and $r_{j t}$ is through $\hat{\gamma}_{w, j t}$ and $\hat{\gamma}_{r, j t}$. Substituting into (2.4) and (2.5) yields $Q_{\mathrm{H}, \mathrm{jt}}$ and $Q_{\mathrm{F}, \mathrm{jt}}$ for each city and year.

\section{Data}

Data for the wage and rent hedonic regressions were obtained, respectively, from the March files of the Current Population Survey (CPS) and the American Housing Survey (AHS) for the 1977 to 1995 period. $^{2}$ Using these data, $\bar{Z}, \bar{X}$, and $\bar{D}$ in (2.8) and (2.9) were set equal to their 1980 sample means, the same reference point used by Blomquist et al. (1988) and Gyourko and Tracy (1991). The wage variable in (2.6) is the total annual salary earnings of the worker. Because commercial rents were unavailable, for (2.7) and (2.9) residential rents from the AHS were used in constructing both $\mathrm{Q}_{\mathrm{H}}$ and $\mathrm{Q}_{\mathrm{F}}{ }^{3}$ Rents were calculated based on gross rents for renter-occupied units and owners' estimates of house value for owner-occupied units. Owners' house values were further converted to annual rents using Peiser and Smith's (1985) discount rate of 7.85 percent as in Gyourko and Tracy (1991) and Blomquist et al (1988). Sample sizes vary across datasets and years of analysis. ${ }^{4}$ As an example, in 1978, the AHS and CPS samples used for the hedonic regressions had 23,734 and 13,981 observations, respectively. In total, 38 hedonic regressions were run, results from which are not presented to conserve space.

Population data for cities in the hedonic regressions were obtained from Census Department publications including the State and Metropolitan Area Data Books and the Statistical Abstract of the United States. The data were collected on a county-level basis and aggregated to compute metropolitan

\footnotetext{
${ }^{2}$ While the CPS data were obtained annually for each year from 1977 to 1995, the AHS data were available on an annual basis only for the years from 1977 to 1983. After 1983, Census collected the AHS data on a biannual basis. To fill in the missing years, quality adjusted building rents were linearly interpolated from the adjacent years.

${ }^{3}$ This is consistent with the Commerce Department practice of using residential price indexes to estimate the price deflators for both residential and non-residential real estate in the National Income and Product Accounts (NIPA).

${ }^{4}$ To be included in the wage sample, an individual needed to be a full-time worker earning in excess of $\$ 1,000$ per year. When estimating the rent hedonic, excluded from the housing sample were mobile homes, public housing units, rent controlled units, and other government subsidized units. In both cases, to be included in the sample an observation (individual or housing unit) had to be located in an identified MSA.
} 
area population levels (based on 1993 Census definitions of the metropolitan areas). From these sources, a balanced panel of the key series was constructed for 37 cities from 1977 to $1995 .^{5}$

\section{Metropolitan Rankings of Quality of Life and Quality of Business Environment}

Table 1 reports quality of life and business environment measures for each of the 37 cities over the 1977 to 1995 period. All values are in 2002 dollars and equal the average of the city-quality measure using every other year in the sample. Bi-annual averaging simplifies construction of the standard errors because the CPS sample turns over entirely every two years as do the occupants of many homes in the AHS sample. ${ }^{6}$ Accordingly, standard errors in Table 1 equal $\frac{1}{10} \sqrt{\operatorname{Var}\left(Q_{1977}\right)+\operatorname{Var}\left(Q_{1979}\right)+\ldots+\operatorname{Var}\left(Q_{1995}\right)}$ with the covariance terms across years set to zero while the variance of $Q$ in year $\mathrm{t}$ is calculated based on the estimated covariance matrix for the hedonic fixed effect coefficients from that year.

Observe that the range in estimates for $Q_{\mathrm{H}}$ from lowest to highest is roughly $\$ 16,500$ while the interquartile range (from 25 th to 75 th percentile) is $\$ 4,400$. These values are close to those of Gyourko and Tracy (1991). ${ }^{7}$ In both studies, older industrialized cities such as Detroit, Kansas City, Baltimore, Cleveland, Cincinnati, Gary, and Akron, were ranked among the lowest quality-of-life metropolitan areas, whereas warmer coastal cities such as Miami, San Diego, San Francisco, San Jose, Sacramento, and Los Angeles were among the highest quality of life cities. Finally, although the standard errors in Table 1 are large enough to make precise ordering of closely ranked cities uncertain - especially in the middle quartiles of the rank distribution - they are small enough to confidently order most of the cities. ${ }^{8}$

\footnotetext{
${ }^{5}$ In the 1970s, the CPS identified only the 39 largest cities in the United States. Two of these cities were dropped because population could not be measured within a fixed set of geographic boundaries over time.

${ }^{6}$ Most renters move within two years of arriving in their home although homeowners are less mobile.

${ }^{7}$ Gyourko and Tracy (1991) report values of $\$ 18,099$ and $\$ 3,265$ (adjusted to 2002 dollars) using 1980 census data.

${ }^{8}$ The comparisons above are based on the second model in Table 3 of Gyourko and Tracy (1991): "Random Effects, Group Effects Included". That model is the closest to the fixed effects approach used here. Note, also, that the median standard error of $\mathrm{Q}_{\mathrm{H}}$ and $\mathrm{Q}_{\mathrm{F}}$ across individual cities and years in our sample was $\$ 2,640$ which is also close
} 
A striking result emerges when comparing household and firm city valuations. Many of the cities less attractive to households are more attractive to industry. Detroit, for example, was ranked 37 by households but was ranked $9^{\text {th }}$ by firms; conversely, Miami was ranked 1 by households but $34^{\text {th }}$ by firms. In addition, the correlation between the $\mathrm{Q}_{\mathrm{H}}$ and $\mathrm{Q}_{\mathrm{F}}$ values in the table is roughly 5 percent. These findings suggest that firms and households often prefer different cities, consistent with the different goals of the two groups. ${ }^{9}$ Moreover, these findings are suggestive that for a city to grow large, either households must want to live in the city - pushing labor supply out as in Miami - or firms must want to do business in the city - pushing labor demand out as in Detroit - or both as in New York, San Francisco, and Los Angeles.

\section{Metropolitan Quality and the Size and Composition of Cities}

This section explores the relationship between urban quality and the size and composition of cities. In this context, city size is measured by the $\log$ share of workers in city $\mathrm{j}$, or $\log \left(\mathrm{N}_{\mathrm{j}} / \mathrm{N}_{\text {sys }}\right)$, where $\mathrm{N}_{\mathrm{j}}$ is the number of workers in city $\mathrm{j}$ and $\mathrm{N}_{\mathrm{sys}}$ is the number of workers in the system of 37 cities. City composition is measured by the $\log$ share of retirees less the $\log$ share of workers, $\operatorname{or} \log \left(\mathrm{R}_{\mathrm{j}} / \mathrm{N}_{\mathrm{j}}\right)-$ $\log \left(R_{\text {sys }} / N_{\text {sys }}\right)$, where $R_{j} / N_{j}$ is the retiree-worker ratio in city $j$ and $R_{\text {sys }} / N_{\text {sys }}$ is the ratio over all cities.

Figures 1 through 4 plot the key series for each city over time. Note that the quality series display little trending (Figures 1 and 2), whereas the worker share series are strongly trended (Figure 3), and the retiree-less-worker share series are moderately trended (Figure 4). Next, we check each of the individual series for unit roots using augmented Dickey-Fuller (ADF) tests allowing for trends in each of the series. In most cases, results fail to reject the null of a unit root implying that the series are I(1). It should be emphasized, however, that these tests have low power especially given that we only have 19 time periods

to standard errors in Gyourko and Tracy (1991) adjusting to 2002 dollars. In contrast, the smaller standard errors in Table 1 are obtained because of the larger sample sizes used to calculate the biannual average values.

${ }^{9}$ These patterns also persist over time. We regressed the biannual averages for $\mathrm{Q}_{\mathrm{H}}$ and $\mathrm{Q}_{\mathrm{F}}$ over the 1987 to 1995 period on their corresponding biannual averages from the 1977 to 1985 period. Coefficients on the lagged variables in the $\mathrm{Q}_{\mathrm{H}}$ and $\mathrm{Q}_{\mathrm{F}}$ regressions were .866 and 1.07, respectively, with t-ratios in excess of 10 and $\mathrm{R}^{2}$ values above 0.7 . 
for each series. ${ }^{10}$ Bearing that caveat in mind, evidence that the series are $\mathrm{I}(1)$ is consistent with theoretical arguments that as a city grows larger relative to other areas, it gains a comparative advantage because of urbanization economies, and therefore grows larger still (e.g. Helsley and Strange (1994)).

Table 2 presents results from regressions of the population series on $\mathrm{Q}_{\mathrm{H}}$ and $\mathrm{Q}_{\mathrm{F}}$. For each dependent variable, several different specifications are presented to check robustness. Model I pools the time series and cross-section data and estimates by OLS. Model II adds city fixed effects. Model III adds year fixed effects, and Model IV replaces the year fixed effects with city-specific time trends. ${ }^{11}$ In all cases, coefficients on $\mathrm{Q}_{\mathrm{H}}$ and $\mathrm{Q}_{\mathrm{F}}$ are constrained to be alike across cities. It should also be emphasized that our primary goal in presenting these alternative specifications is to establish robustness with respect to the signs on the slope coefficients in the models.

Before examining the results, it is desirable to highlight the reduced form nature of the worker share regression as this has implications for priors governing the model coefficients. On the one hand, labor supply and demand shift out in response to improvements in $\mathrm{Q}_{\mathrm{H}}$ and $\mathrm{Q}_{\mathrm{F}}$, respectively. This implies a positive relationship between urban quality and city size. On the other hand, a large literature on agglomeration economies (e.g. Glaeser et al (1992), Henderson et al (1995), Eberts and McMillen (1999), Rosenthal and Strange $(2002,2003))$ suggests that city size lowers production costs. That, in turn, would cause $\mathrm{Q}_{\mathrm{F}}$ to increase. Unambiguously, therefore, we anticipate a positive relationship between worker shares and $\mathrm{Q}_{\mathrm{F}}$. In contrast, priors governing the manner in which households view city size are less clear. Larger cities offer cultural amenities, but also congestion, crime, and related problems. Accordingly, the relationship between worker shares and $\mathrm{Q}_{\mathrm{H}}$ is ambiguous.

\footnotetext{
${ }^{10}$ The ADF tests were conducted separately for each series in each of the 37 cities. Each test includes a constant, a time trend, one lag of the dependent variable, and is based on 19 time periods. For each series, the number of cities for which the null of a unit root could be rejected at the 10 percent level is, respectively: for $\mathrm{Q}_{\mathrm{H}}, 2$ cities; for $\mathrm{Q}_{\mathrm{F}}, 5$ cities; for $r, 0$ cities; for $\log$ (city worker shares), 5 cities; and for $\log$ ([city worker share]/[city retiree share]), 9 cities.

${ }^{11} \mathrm{We}$ also estimated each of these models a second time including one lead and one lag of the first difference of each of the slope variables to control for serial correlation over time as discussed by Saikkonen (1991). Results from these specifications were largely similar to those in Table 2 and are not presented to conserve space.
} 
Results in the top panel of Table 2 are consistent with these priors, where the dependent variable is the log of city worker shares. For each model specification, the coefficient on $\mathrm{Q}_{\mathrm{F}}$ is positive and significant. In contrast, the coefficient on $\mathrm{Q}_{\mathrm{H}}$ varies in sign across model specifications. Given evidence of trending behavior in the worker share series in Figure 3, Model IV not surprisingly provides the closest fit to the data as indicated by the lowest root mean squared error.

Consider next city composition. It seems unlikely that the ratio of retirees to workers has much effect on $\mathrm{Q}_{\mathrm{H}}$ and $\mathrm{Q}_{\mathrm{F}}$. Accordingly, the city composition regressions are interpreted as shedding light on whether there is a causal effect of $\mathrm{Q}_{\mathrm{H}}$ and $\mathrm{Q}_{\mathrm{F}}$ on the $\log$ ratio of retirees to workers. Because firms compete for space with retirees - causing housing prices to rise - without offering retirees direct pecuniary compensation (e.g. wages), we expect an increase in $\mathrm{Q}_{\mathrm{F}}$ to diminish the presence of retirees relative to workers. However, the influence of $\mathrm{Q}_{\mathrm{H}}$ is ambiguous once more since both workers and retirees prefer attractive (high $\left.\mathrm{Q}_{\mathrm{H}}\right)$ cities, ceteris paribus.

Once again, results in Table 2 support the priors. In the middle panel of the table, observe that for all four models, $\mathrm{Q}_{\mathrm{F}}$ has a negative and highly significant effect on the presence of retirees relative to workers. In contrast, the coefficient on $\mathrm{Q}_{\mathrm{H}}$ varies in sign and significance across the models.

As a final exercise, the bottom panel of Table 2 repeats the city composition regressions replacing $\mathrm{Q}_{\mathrm{F}}$ with land rents $(r)$. The discussion above suggests that retirees should unambiguously prefer high quality of life cities after controlling for land rents, and that high land rents should discourage retirees from locating in a city. Observe that for all four models, land rent has a negative and highly significant effect on the presence of retirees relative to workers. Similarly, $\mathrm{Q}_{\mathrm{H}}$ always has a positive effect that is significant in all models except for Model II. These findings complement those above and suggest that relative to workers, retirees are drawn towards low cost cities. ${ }^{12}$

\footnotetext{
${ }^{12}$ In principle, the models in Table 2 could also be used to test for whether the city population and quality series cointegrate in the manner specified by the different regressions. In this regard, it should be noted that Model IV is difficult to interpret since it is not clear what drives the city-specific time trends (Models II and III, in contrast, simply demean the data). Also, for all of the models, our ability to test for cointegration is low given the short time series. Nevertheless, ADF tests with one lag were conducted to check the residuals from each of the models in Table
} 


\section{Conclusions}

This paper shows that many of the cities least attractive to households are most attractive to firms, and vice versa. Moreover, cities appear to gain workers and grow in size as the quality of the business environment becomes more attractive. Our findings also have important implications for the demographic composition of cities. With the aging of the baby boomers, cities are increasingly sensitive to the location preferences of retirees. ${ }^{13} \mathrm{We}$ show that the cities most likely to be dominated by retirees are those that are less attractive to firms, and more generally, cities attractive to households with low house prices. These findings support arguments by Graves and Knapp (1988) that retirees tend to seek out cities where local attributes are capitalized into lower wages rather than higher land rents. These findings also suggest that local government policies designed to attract industry may inadvertently cause retirees to relocate to other cities.

2 for unit roots, where rejecting the null of a unit root implies cointegration (Engle and Granger (1987)). For the worker share regressions, at the 5 percent level, the null is rejected in 3, 6, 8, and 23 cities for Models I through IV, respectively; for the retiree-less-worker share regressions the analogous values are $4,8,8$, and 18 cities. These results are suggestive that the series do not cointegrate. However, for reasons noted above, the issue of cointegration is better studied in a longer time series and is left for future research.

\footnotetext{
${ }^{13}$ Recognizing this, a number of states have developed marketing programs designed to advertise their amenities to recent retirees [Fagan (1988), Stallman and Siegle (1995), Wilkinson (1995)]. In addition, many states have enacted tax policies designed to attract and retain retirees [Stockbridge-Pratt (1997)].
} 


\section{References}

Blomquist, Glenn, Mark Berger, and John Hoehn, "New Estimates of the Quality of Life in Urban Areas", American Economic Review, 78, 89-107 (1988).

Boyer, R. and Savageau, Places Rated Almanac, Prentice Hall, New York, (1985, 1989, 1993)

Eberts, R.W. and D. P. McMillan (1999), "Agglomeration economies and urban public infrastructure," in P. Cheshire and E.S. Mills (eds.), Handbook of Urban and Regional Economics, Volume 3, New York: North Holland, 1455-1495.

Engle, R. F. And C. W. J. Granger, "Cointegration and Error Correction: Representation, Estimation and Testing," Econometrica, 55, 251-276, (1987).

Fagan, Mark (1988), “Attracting Retirees for Economic Development,” (Jacksonville, AL. Jacksonville State University Center for Economic Development).

Forbes Magazine, May 2002, http://www.forbes.com/finance/lists/setters/listHomeSetter.jhtml?passListId=1.

Gabriel, Stuart, Joe Mattey and William Wascher, "Compensating Differentials and Evolution of the Quality-of-Life Among U. S. States". Regional Science and Urban Economics, forthcoming, 2003.

Glaeser, E.L, H. D. Kallal, J. A. Scheinkman, and A. Shleifer (1992), "Growth in Cities." Journal of Political Economy, 100, 1992, 1126-1152.

Graves, Philip E. and Thomas A. Knapp, "Mobility Behavior of the Elderly," Journal of Urban Economics, 24, 1-8 (1988).

Gyourko, Joseph and Joseph Tracy, "The Structure of Local Public Finance and the Quality of Life", Journal of Political Economy, vol. 99, no. 4, 774-806 (1991).

Helsley, W. Robert and William C. Strange, "City Formation With Commitment," Regional Science and Urban Economics," 24, 373-390 (1994).

Henderson, J.V., A. Kuncoro and M. Turner (1995), "Industrial Development in Cities." Journal of Political Economy 103, 1067-1085.

Kahn, Matthew, "A Revealed Preference Approach to Ranking City Quality of Life," Journal of Urban Economics,38, 221-235 (1995)

MacKinnon, James G., "Critical Values for Cointegration Tests," in Engle R.F. and C.W.J. Granger eds., Long-Run Economic Relationship, Oxford University Press, New York, 1991.

Money Magazine, 2002, http://money.cnn.com/best/bplive/.

Peiser, Richard B., and Lawrence B. Smith, "Homeownership Returns, Tenure Choice and Inflation." American Real Estate and Urban Economics Association Journal, 13 (Winter 1985), 343-60.

Roback, Jennifer, "Wages, Rents, and the Quality of Life", Journal of Political Economy, 90, 1257-78 (1982). 
Rosenthal, Stuart S. and William C. Strange, "Geography, Industrial Organization, and Agglomeration," Review of Economics and Statistics, May 2003.

Rosenthal, Stuart S. and William Strange, "Evidence on the Nature and Sources of Agglomeration Economies", prepared for the Handbook of Urban and Regional Economics, Volume 4, manuscript, December 2002.

Saikkonen, Pentti, “Asymptotically Efficient Estimation of Cointegration Regressions," Econometric Theory, 7, 1-21 (1991).

Stallmann, Judith and Paul Siegel (1995), "Attracting Retirees as an Economic Development Strategy: Looking into the Future," Economic Development Quarterly 9, pp. 372-382.

Stockbridge-Pratt, Dorothy (1997), "Going Up; Kings Island Estates, Desoto County; County's Lower Fees are Attracting Retiree Buyers," Sarasota Herald-Tribune (November 23), p. 1I.

Wilkinson, David (1995), "States Court Retirees, Their Bank Accounts and Habits," The [Charlston, WV] Sunday Gazette Mail (July 23), p. 2A. 
Table 1

1977 to 1995 Average Values of Quality of Life and Quality of Business Environment*

(All values are in $2002 \$$; Rank = 1 is best, Rank = 37 is worst)

Differences in $Q_{H}$ reflect the amount a household values one city over the other. Differences in $Q_{F}$ reflect the amount a firm values one city over the other per worker

\begin{tabular}{|c|c|c|c|c|c|c|}
\hline & \multicolumn{3}{|c|}{ Quality of Life $\left(Q_{H}\right)$} & \multicolumn{3}{|c|}{ Quality of Business Environment $\left(Q_{F}\right)$} \\
\hline Metropolitan Area & $\begin{array}{c}\text { Rank Avg } \\
77-95\end{array}$ & $\begin{array}{c}\text { Avg } \\
77-95\end{array}$ & $\begin{array}{c}\text { Stnd } \\
\text { Err }\end{array}$ & $\begin{array}{c}\text { Rank Avg } \\
77-95\end{array}$ & $\begin{array}{c}\text { Avg } \\
77-95\end{array}$ & $\begin{array}{c}\text { Stnd } \\
\text { Err }\end{array}$ \\
\hline Miami & 1 & 7990 & 719 & 34 & -4644 & 719 \\
\hline San Diego & 2 & 5247 & 761 & 10 & 3551 & 761 \\
\hline Los Angeles-Long Beach & 3 & 4851 & 642 & 5 & 5962 & 642 \\
\hline San Francisco & 4 & 4420 & 752 & 2 & 10529 & 752 \\
\hline Tampa-St. Petersburg-Clearwater & 5 & 3802 & 746 & 37 & -7044 & 746 \\
\hline New York & 6 & 3533 & 642 & 7 & 5141 & 642 \\
\hline Albany-Schenectady-Troy & 7 & 1786 & 898 & 28 & -2356 & 898 \\
\hline Greensboro--Winston-Salem--High Pt. & 8 & 1558 & 812 & 35 & -4829 & 812 \\
\hline Sacramento & 9 & 1250 & 849 & 18 & 843 & 849 \\
\hline Norfolk-Virginia Beach-Newport News & 10 & 686 & 865 & 30 & -2548 & 865 \\
\hline Seattle-Bellevue-Everett & 11 & -7 & 761 & 6 & 5146 & 761 \\
\hline Denver & 12 & -114 & 728 & 15 & 1775 & 728 \\
\hline Newark & 13 & -141 & 717 & 3 & 8340 & 717 \\
\hline San Jose & 14 & -603 & 794 & 1 & 13187 & 794 \\
\hline Minneapolis-St. Paul & 15 & -959 & 722 & 12 & 2741 & 722 \\
\hline Fort Worth-Arlington & 16 & -1052 & 788 & 31 & -3150 & 788 \\
\hline Birmingham & 17 & -1109 & 862 & 36 & -6129 & 862 \\
\hline New Orleans & 18 & -1219 & 843 & 25 & -1153 & 843 \\
\hline Chicago & 19 & -1448 & 647 & 8 & 3997 & 647 \\
\hline Indianapolis & 20 & -1580 & 876 & 33 & -3509 & 876 \\
\hline Rochester & 21 & -1593 & 829 & 16 & 1450 & 829 \\
\hline Pittsburgh & 22 & -1718 & 733 & 29 & -2365 & 733 \\
\hline Dallas & 23 & -1753 & 708 & 20 & 114 & 708 \\
\hline Columbus & 24 & -1789 & 781 & 26 & -1595 & 781 \\
\hline Washington DC & 25 & -1916 & 656 & 4 & 7579 & 656 \\
\hline Milwaukee-Waukesha & 26 & -2444 & 781 & 14 & 1859 & 781 \\
\hline Philadelphia & 27 & -2471 & 664 & 13 & 2570 & 664 \\
\hline Baltimore & 28 & -2519 & 739 & 11 & 3137 & 739 \\
\hline Cincinnati & 29 & -2743 & 759 & 23 & -801 & 759 \\
\hline Atlanta & 30 & -2785 & 730 & 19 & 196 & 730 \\
\hline Cleveland-Lorain-Elyria & 31 & -2796 & 730 & 21 & 90 & 730 \\
\hline Akron & 32 & -2928 & 915 & 27 & -1872 & 915 \\
\hline Kansas City & 33 & -3056 & 744 & 32 & -3472 & 744 \\
\hline Houston & 34 & -3082 & 689 & 22 & -651 & 689 \\
\hline St. Louis & 35 & -4118 & 774 & 24 & -939 & 774 \\
\hline Gary & 36 & -5982 & 1173 & 17 & 1206 & 1173 \\
\hline Detroit & 37 & -8589 & 671 & 9 & 3645 & 671 \\
\hline
\end{tabular}

${ }^{*}$ The $Q$ averages were formed using every other year of the data beginning in 1977 to reduce spurious correlation when calculating the standard errors as discussed in the text. 
Figure 1: Quality of Life (2-Year Moving Average) - $Q_{H}$ (Vertical Scales Correspond to the Closest City in the Legend and Differ Across Plots)
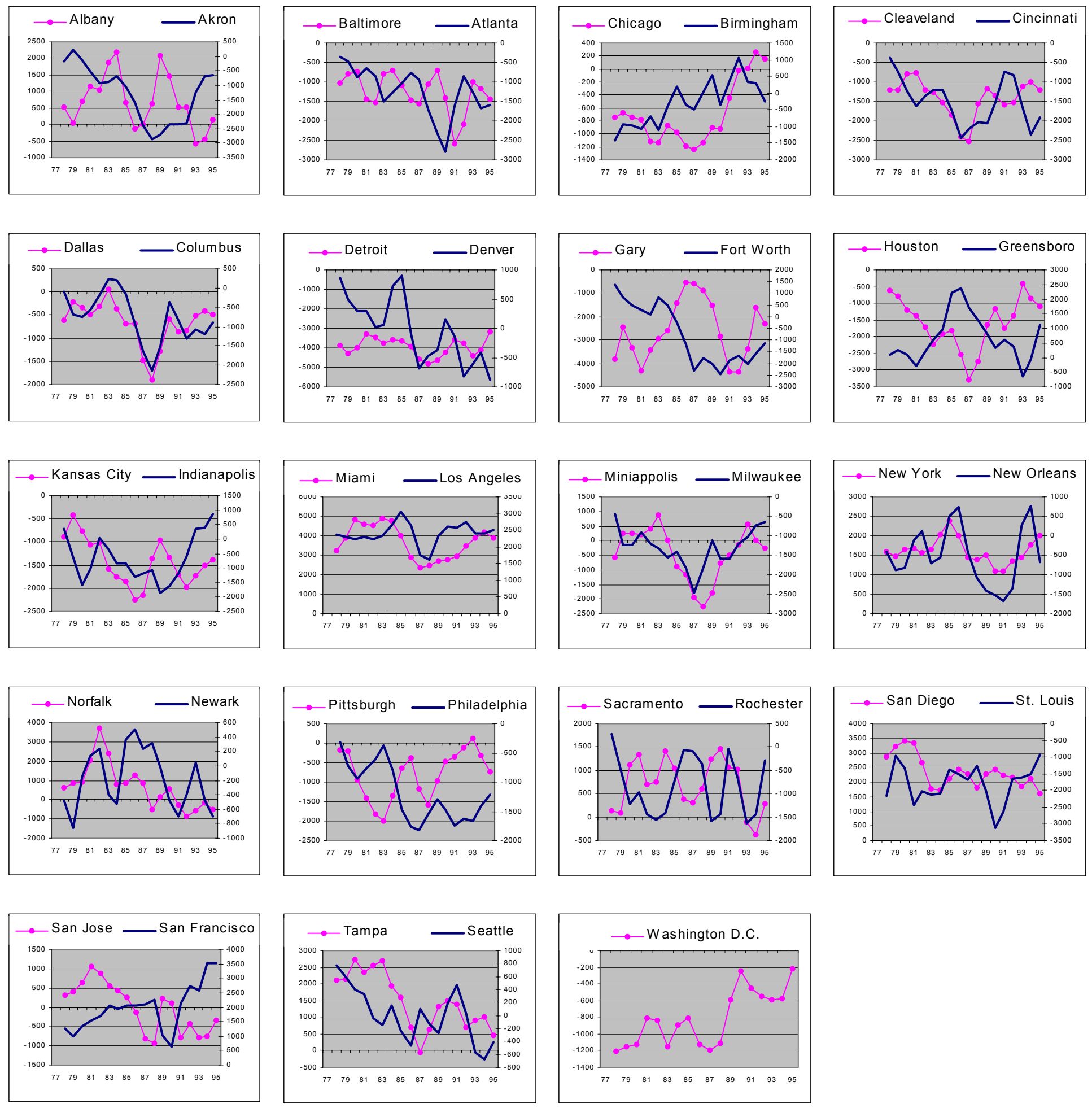
Figure 2: Quality of Business Environment (2-Year Moving Average) - $Q_{F}$ (Vertical Scales Correspond to the Closest City in the Legend and Differ Across Plots)
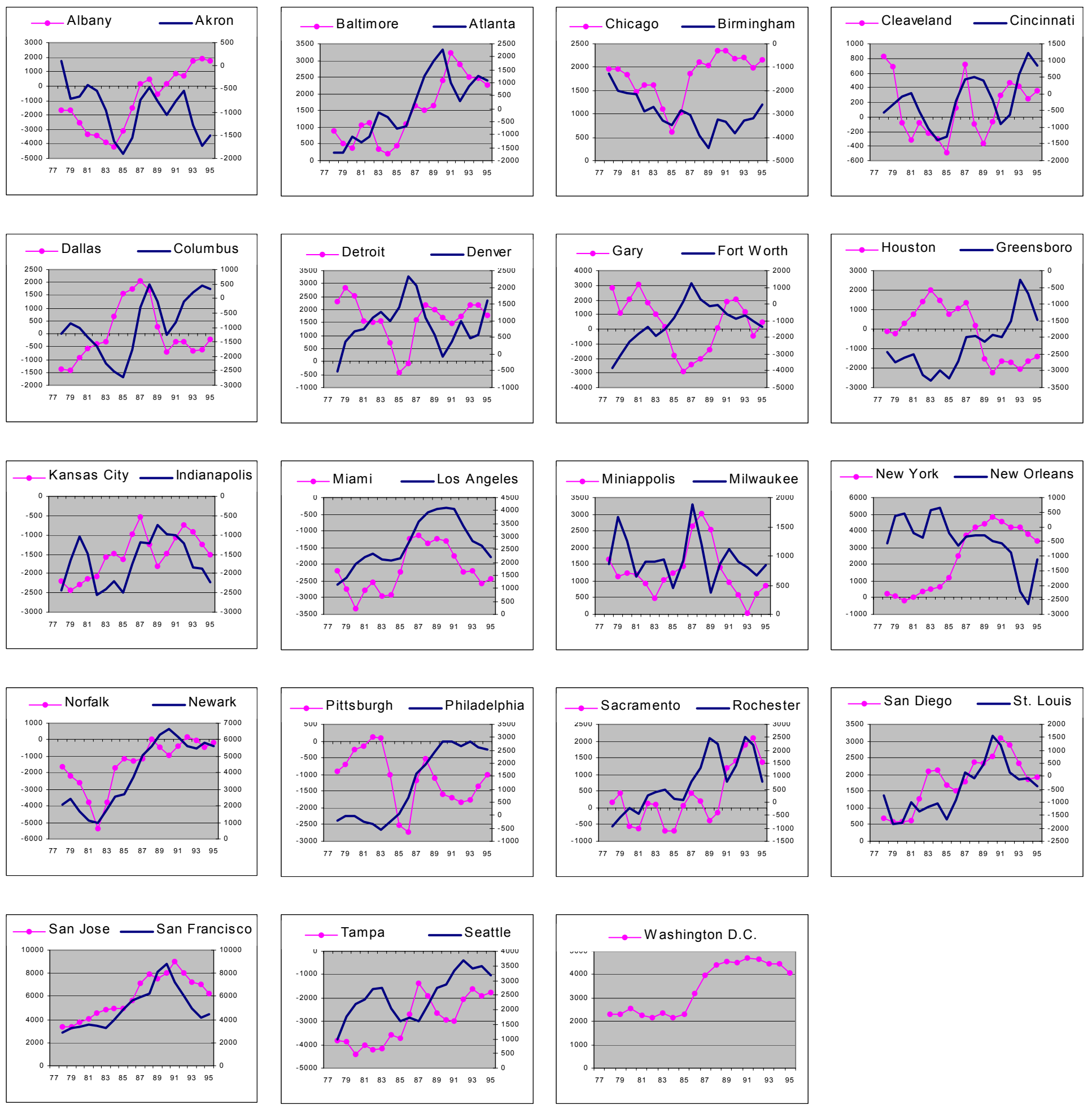
Figure 3: Worker Log-Population Shares (Vertical Scales Correspond to the Closest City in the Legend and Differ Across Plots)
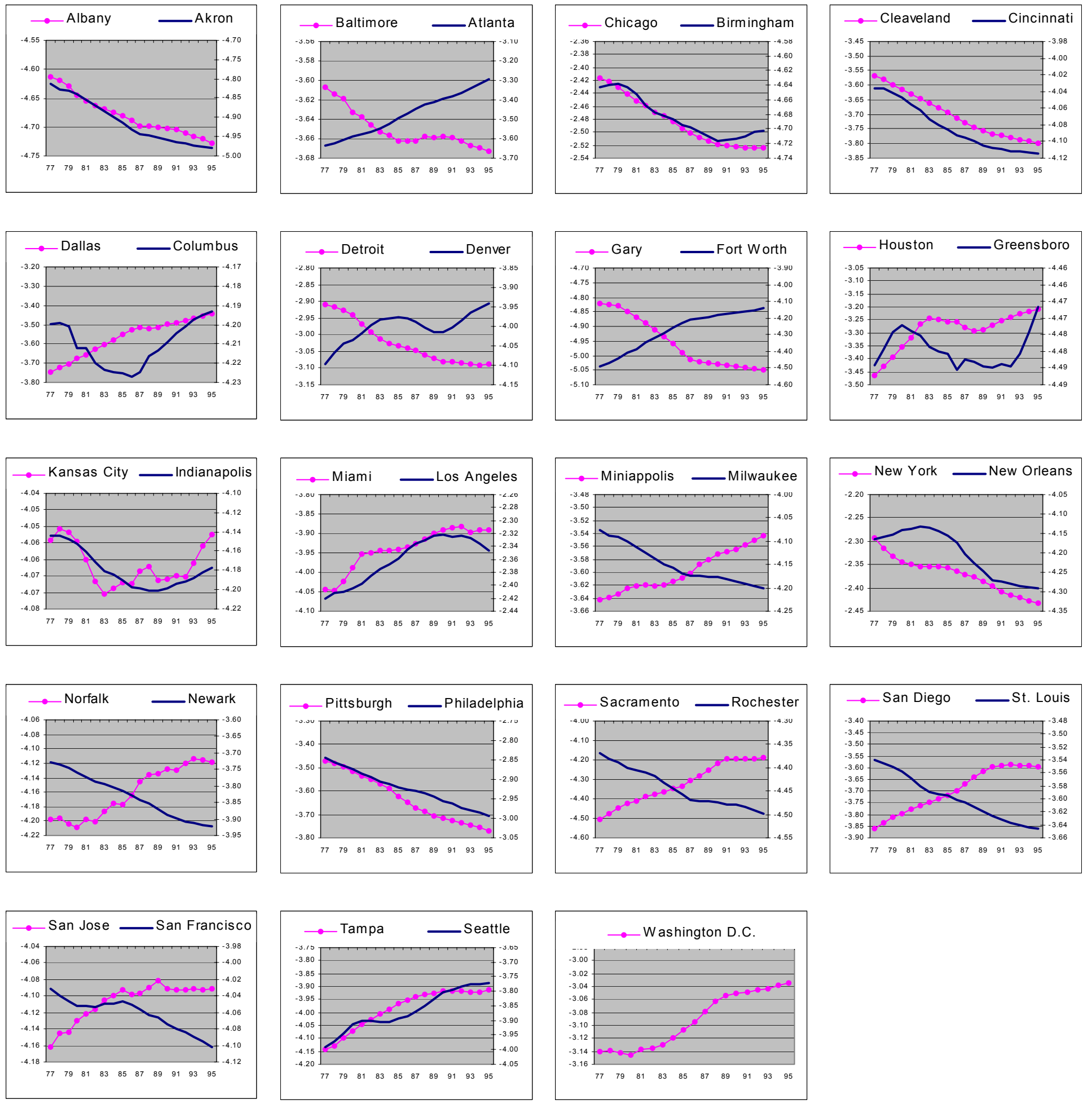
Figure 4: Retiree Log-Population Share Minus Worker Log-Population Share (Vertical Scales Correspond to the Closest City in the Legend and Differ Across Plots)
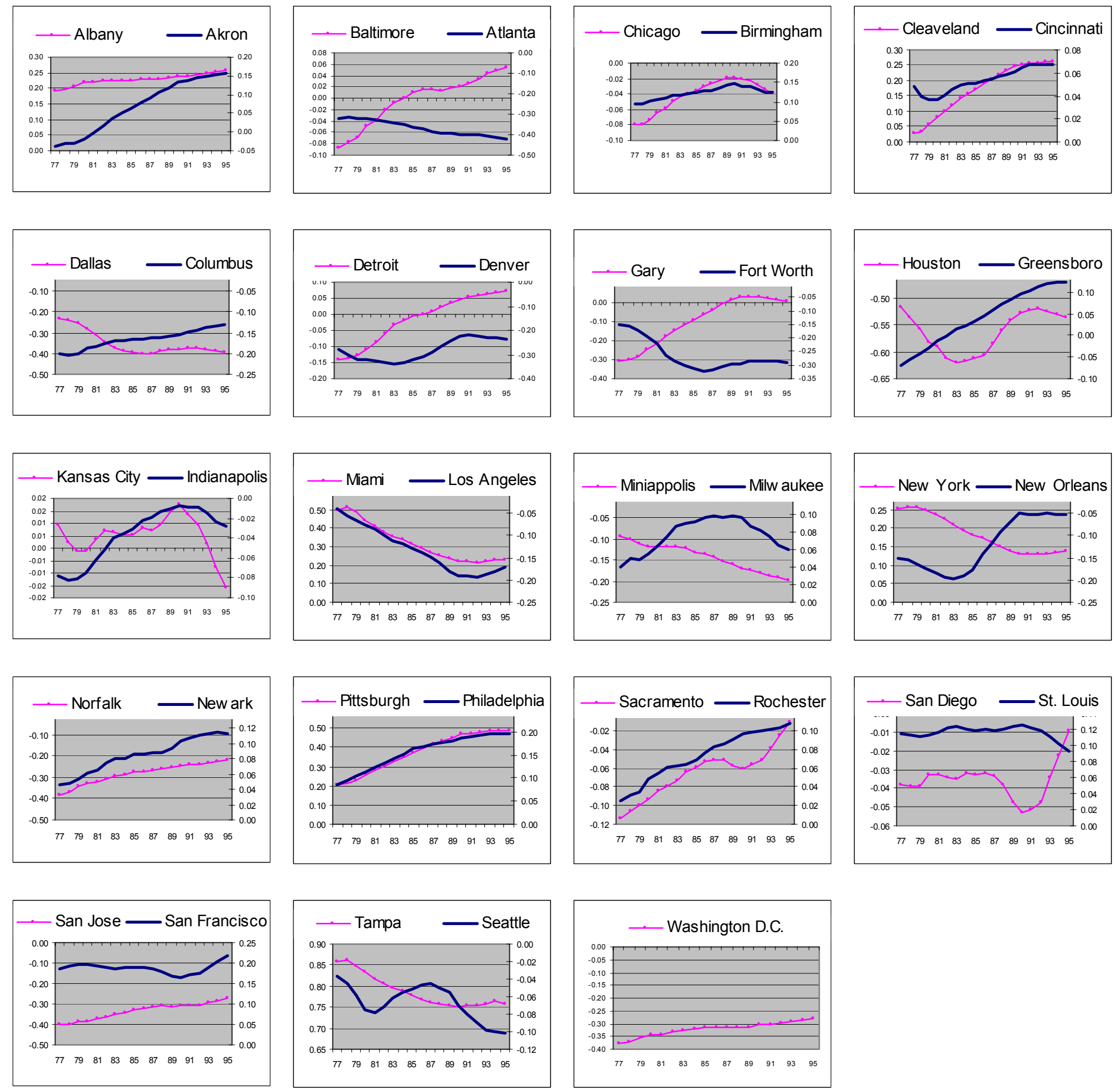
TABLE 2

Metropolitan Quality and City Size

(t-ratios in parentheses; All coefficients are scaled by $10^{6}$ )

\begin{tabular}{|c|c|c|c|c|c|c|c|c|c|}
\hline & $\mathbf{Q}_{\mathrm{H}}$ & $\mathbf{Q}_{\mathrm{F}}$ & $r$ & $\begin{array}{l}\text { City } \\
\text { Fixed } \\
\text { Effects } \\
\end{array}$ & $\begin{array}{l}\text { Year } \\
\text { Fixed } \\
\text { Effects } \\
\end{array}$ & $\begin{array}{l}\text { City } \\
\text { Time } \\
\text { Trends }\end{array}$ & Adj $R^{2}$ & $\begin{array}{l}\text { Root } \\
\text { MSE }\end{array}$ & Obs \\
\hline \multicolumn{10}{|c|}{$\log _{\text {worker share }}{ }^{a}$} \\
\hline Model I & $\begin{array}{l}3.72 \\
(2.76)\end{array}$ & $\begin{array}{l}10.01 \\
(10.6)\end{array}$ & - & No & No & No & 0.137 & 0.592 & 703 \\
\hline Model II & $\begin{array}{l}-0.887 \\
(-2.57)\end{array}$ & $\begin{array}{l}0.512 \\
(2.19)\end{array}$ & - & Yes & No & No & 0.991 & 0.059 & 703 \\
\hline Model III & $\begin{array}{l}-0.910 \\
(-2.56)\end{array}$ & $\begin{array}{l}0.699 \\
(2.68)\end{array}$ & - & Yes & Yes & No & 0.991 & 0.059 & 703 \\
\hline Model IV & $\begin{array}{l}1.09 \\
(10.7)\end{array}$ & $\begin{array}{l}1.33 \\
(16.2)\end{array}$ & - & Yes & No & Yes & 0.999 & 0.012 & 703 \\
\hline \multicolumn{10}{|c|}{$\begin{array}{l}\text { Log retiree share - } \\
\text { Log worker share }^{a}\end{array}$} \\
\hline Model I & $\begin{array}{l}3.29 \\
(6.14)\end{array}$ & $\begin{array}{l}-2.32 \\
(-6.15)\end{array}$ & - & No & No & No & 0.106 & 0.236 & 703 \\
\hline Model II & $\begin{array}{l}-0.386 \\
(-1.32)\end{array}$ & $\begin{array}{l}-0.668 \\
(-3.38)\end{array}$ & - & Yes & No & No & 0.960 & 0.050 & 703 \\
\hline Model III & $\begin{array}{l}-0.650 \\
(-2.38)\end{array}$ & $\begin{array}{l}-1.61 \\
(-8.03)\end{array}$ & - & Yes & Yes & No & 0.966 & 0.046 & 703 \\
\hline Model IV & $\begin{array}{l}-1.15 \\
(-10.08)\end{array}$ & $\begin{array}{l}-1.46 \\
(-15.8)\end{array}$ & - & Yes & No & Yes & 0.996 & 0.016 & 703 \\
\hline \multicolumn{10}{|c|}{$\begin{array}{l}\text { Log retiree share - } \\
\text { Log worker share }^{a}\end{array}$} \\
\hline Model I & $\begin{array}{l}5.61 \\
(9.07)\end{array}$ & - & $\begin{array}{l}-4.64 \\
(-6.15)\end{array}$ & No & No & No & 0.106 & 0.236 & 703 \\
\hline Model II & $\begin{array}{l}0.282 \\
(1.22)\end{array}$ & - & $\begin{array}{l}-1.34 \\
(-3.38)\end{array}$ & Yes & No & No & 0.960 & 0.050 & 703 \\
\hline Model III & $\begin{array}{l}0.962 \\
(4.26)\end{array}$ & - & $\begin{array}{l}-3.22 \\
(-8.03)\end{array}$ & Yes & Yes & No & 0.966 & 0.046 & 703 \\
\hline Model IV & $\begin{array}{l}0.309 \\
(3.83)\end{array}$ & - & $\begin{array}{l}-2.92 \\
(-15.8)\end{array}$ & Yes & No & Yes & 0.996 & 0.016 & 703 \\
\hline
\end{tabular}

${ }^{a}$ Worker $\log$-population share equals $\log \left(\mathrm{N}_{\mathrm{j}} / \mathrm{N}_{\text {sys }}\right)$, where $\mathrm{N}_{\mathrm{j}}$ and $\mathrm{N}_{\text {sys }}$ are the number of workers in city $\mathrm{j}$ and the system of 37 cities, respectively. Retiree less worker log-population share equals $\log \left(R_{j} / N_{j}\right)-\log \left(R_{\text {sys }} / N_{\text {sys }}\right)$, the ratio of retirees to workers in city j less the log ratio of retirees to workers for the entire system of cities. 